\title{
Challenges facing women entrepreneurs in accessing business finance in Kenya: Case of Ruiru Township, Kiambu County
}

\author{
Phylis Makena, Simon Thiaine Kubaison, Charles Ibuathu Njati.
}

\section{Introduction}

There are various definitions of Small and Medium Enterprises (SMEs), varying between countries and their levels of economic development. The definition is also based on considerations such as the number of employees and revenue levels. In the United States and European Union (EU) countries SMEs are enterprises with employees under 500 while in developing countries any enterprise employing below 100 employees would constitute an SME. In Kenya, Small enterprises are defined as enterprises employing between 1-50 employees, while medium enterprises are those with 51-99 employees (GoK, 1999).

Globally, SMEs are believed to play a pivotal role in promoting grassroots economic growth and equitable sustainable development. As SMEs have become essential in the economic matrixes of the nations, increased deliberate government policies and legislation have been witnessed globally, in the government quest to nurture SMEs. It is also estimated that SMEs constitute over 90 percent of total enterprises in most economies with a high rate of employment growth. They are also a vehicle for increased industrial production and exports. For example, in Kenya it is estimated that SMEs contribute over 60 percent in employment and 55 percent to Gross Domestic Product (GDP) (GoK), 2005). The Asian Tigers such as India, Indonesia, China, Malaysia, Japan, and South Korea also have thriving SMEs sectors contributing between 7090 percent in employment and an estimated 40 percent contribution to their respective GDPs. It is my view, in the chase of millennium goals, it is extremely vital to re-define the role of SMEs as important economic growth and employment drivers.

In African countries, for instance Kenya, it is believed that SMEs face daunting challenges that have always suppressed their robust growth (GoK), 2005). Among these challenges are; lack of managerial expertise, inadequate education and skills, lack of credit, technological change, poor infrastructure and insufficient markets information among others. This has affected the profitability of the SMEs.

SME financing is the funding of small and medium enterprises and represents a major function of the general business finance market in which capital for different types of firms are supplied, acquired and costed or priced. Capital is supplied through the business finance market in the form of bank loans and overdrafts, leasing and hire-purchase arrangements, equity/corporate bond issue, venture capital and asset based finance such as factoring and invoice discounting. Women owned businesses are known for their low start-up and working capital. Siwadi and Mhagari (2011), Gen (2003) notes that under normal circumstances, women's enterprises have low growth rate and are limited potentially due to the type of the business they operate.

\section{Women Entrepreneurs}

In Kenya, women owned businesses account for over $48 \%$ of all SMEs (ILO, 2008). Stevenson and St-Onge (2005) contends that there are three profiles of women entrepreneurs operating SMEs in Kenya namely; Jua Kali micro-enterprises, very small micro enterprises and small scale enterprises. These are differentiated by their demographic profiles, extent of previous business experience, needs, access to resources and growth orientation. The bulk of women entrepreneurs in Kenya operate enterprises associated with traditional women's roles such as, hairstyling, restaurants, hotels, retail and wholesale outlets (ILO, 2008). Women owned enterprises are making a significant contribution to the Kenyan economy, accounting for $20 \%$ of Kenya's GDP. Of the 462,000 jobs created annually since 2000 in Kenya, 445,000 jobs have emanated from the informal sector, where $85 \%$ of women's businesses are found. (Voices of Women entrepreneurs, Kenya).

Female entrepreneurship has received growing attention in recent years, both at the academic and policy level. Their contribution to the economy is noted to be higher than that of men in entrepreneurial activities (Miniti, 2010) .The role of women in creating, running, and growing businesses is recognized as fundamental for growth and poverty reduction. In many countries, women are starting businesses at a faster rate than men. However, women entrepreneurs tend to face disproportionately larger obstacles in accessing credit, training, networks and information in addition to barriers in the legal and policy framework and as a result may not achieve the same level of performance as their male counterparts. According to the World Bank Group's Enterprise Surveys (2007-20120), women own more than 34\% of registered businesses in developing countries. 
This adds up to a significant contribution by women entrepreneurs to job creation, income generation, and economic growth.

Meanwhile, many businesswomen cannot access commercial credit, an essential driver of business success. As a result, women-owned businesses are disproportionately micro, small or medium enterprises that may not mature to their full potential. This represents a missed opportunity for financial institutions and has negative implications for the private sector as a whole.

\section{Problem Statement}

Over 98\% of SMEs have no access to formal financing (Ayyagari, Demirgüç-Kunt and Maksimovic, 2006; Beck et al. 2006). Lin (2007) contends that small firms tend to face greater financial constraints than do larger firms. An IFC study of 10,000 firms across 80 countries found that credit is mentioned more frequently by smaller firms as a constraint on growth (Schiffer and Weder, 2001). In Kenya, many Surveys reveal that lack of capital is a strong constraint to growth (National Baseline Survey, 1993; 1995; 1999; Stone, et al.1992).

The Central Bank of Kenya (2007) reports the existence of 5122 registered savings and credit co-operatives (SACCOs), 45 banking institutions, 42 of which were commercial banks, 2 mortgage finance companies and 1 non-banking financial institutions. A more comprehensive study conducted by the Central Bank in June 2003 estimated at 3,460 the number of legally constituted microfinance service providers in Kenya, including 3,397 SACCOs and co-operative-like community-based intermediaries, 56 microfinance institutions (MFIs), four commercial banks, two building societies, and the Kenya Post Office Savings Bank (http://www.mfi-upgradinginitiative.org). These financial institutions provide a broad source of finances for business development, yet women still face immense challenges in accessing finance. The researcher was interested in establishing the key challenges which limit the accessibility of finance by women entrepreneurs in Kenya, Ruiru municipality.

\section{Objectives of the study}

- To find out the extent to which lack of collateral limits the accessibly of finance by women entrepreneurs in Kenya, Ruiru municipality

- To determine the influence of cultural norms and family responsibilities on the accessibility of credit by women entrepreneurs in Kenya, Ruiru municipality.

- To find out the extent to which insufficient information limits the accessibility of finance by women entrepreneurs in Kenya, Ruiru municipality.

- To determine some of the gender discriminatory factors which limit the accessibility of finance by women entrepreneurs in Kenya, Ruiru municipality.

\section{- Hypotheses}

$\mathrm{HO}_{1}$ : Lack of collateral does not limit the accessibility of finance by women entrepreneurs in Kenya

$\mathrm{HO}_{2}$ : Cultural norms do not limit the accessibility of finance by women entrepreneurs in Kenya.

$\mathrm{HO}_{3}$ : Insufficient information does not limit the accessibility of finance by women entrepreneurs in Kenya

$\mathrm{HO}_{4}$ : Gender discrimination factors do not limit accessibility of finance by women entrepreneurs in Kenya.

\section{Insufficient information on finance}

\section{Literature Review}

Access of information is important both from the SME perspective and from the provider of the financial services. The SMEs requires information in which to identify the potential supplier of the financial services. This information is useful in evaluation of the cost of the financial services that are being offered. Lack of awareness about financial assistance in the form of loans and schemes by the institution in the financial sector, hinders the sincere effort towards women entrepreneurs from reaching those in the rural and backward areas. Poor understanding of financial terminologies and lack of understanding of credit processes and the role of credit bureaus places women at a disadvantage. Despite the resources available, from private and public development finance institutions, few women know about them, their products and how to access them. Even when they have access to information on the financial services and market opportunities available to them, women may be less equipped to process it. Their lower levels of literacy and lack of exposure to other languages, especially relative to male family members, hampers women's ability to benefit directly from information that is provided in writing or in languages other than those they speak at home (UNDP, 2007 and Ngimwa et al., 1997) and to fully understand the conditions of complex financial products available to them (Brown, 2001). This matters as demonstrated by Cole et al.'s (2009) experimental work in India and Indonesia that finds financial literacy as a strong predictor of demand for financial services. This is worsened by the low level of training among women entrepreneurs. This reality of perception of women's low education, skill level and work experience may further lessen their attractiveness to lenders. Entrepreneurial education and training has been noted to have a significance role in stimulating entrepreneurship and self-employment (Namusonge, 
2006). Women entrepreneurs are also noted to be operating under low levels of technology which is not appropriate for their entrepreneurial operations (UNIDO; 2003, GoK; 2005). Research also shows that majority of women entrepreneurs in Kenya who are located around Nairobi, come from disadvantaged social backgrounds and are not well informed about business process operations hence fail to take opportunities as the y come along (ILO;2008).

\section{Cultural norms}

Socially accepted norms of behaviour and the roles women play in their families can have intense effects on the type of economic activities in which women can be involved, the technologies available to them, the people and agencies with whom they can interact, the places they can visit, the time they have available and the control they can employ over their own capital. The African culture still places a woman in the kitchen together with taking care of the children. According to the report by Gender and Monitoring Unit, women also have been a victim of gender violence domestically, emotionally and psychologically (GoK; 2006). This has made it worse for women to participate fully in entrepreneurship due to the fear.

In settings where socio cultural norms restrict women's mobility, their ability to attend trainings or receive formal education, access to information, institutions and markets is compromised. The location of their businesses at home as noted by Marlow (2002), may also seem to underrate the legitimacy of the businesses as perceived by their potential customers and creditors. As a result of these constraints, rural women tend to get their information from informal networks of women, reinforcing the gender gap in access to information. The gap can be substantial: recent work to quantify it using data from Paraguay compares husbands' and wives' knowledge of financial markets and finds that rural women are 15 to 21 percent less likely than men to have basic information about the financial institutions in their communities (Fletcher and Mesbah, 2010).

\section{Lack of collateral}

Globally, women face legal obstacles in starting and running a business. According to World Bank report (2012) on Women Business and Law, women in Middle East and North African countries have fewer inheritance rights than men. The report also indicates that women only own one percent of the world's property and in two thirds of countries, legal rights of women decline with marriage. In Kenya although inheritance laws were raised with the succession Act of 1981 women have rarely inherited land and other property in their own rights. Legal regulations and customary rules often restrict women's access to and control over assets that can be accepted as collateral such as land or livestock. Women are much less likely to have land titled under their name, even when their families own land, and are less likely than men to have control over land, even when they do formally own it. Biased inheritance rights often grant land to male relatives, leaving both widows and daughters at a disadvantage (Agarwal, 2003). Neither the state mandated agrarian reforms of past decades that granted much of the land to "household heads," who were typically men, nor the more recent market-assisted land reforms have led to significant improvements in women's access to and control over land (Deere and Leon, 1997 and Bezner Kerr, 2008). Even in countries where laws do protect women's land rights, these laws tend to be loosely regulated and implemented (USAID, 2003). Women's control over their families' livestock varies by culture (Tipilda and Kristjanson, 2008). Yet, typically, men are responsible for the purchase, sale or pawning of large animals, such as cows, horses and oxen, while women tend to claim control over small animals such as goats, sheep, poultry and pigs (World Bank, 2008b; IFAD, 2004, and; Miller, 2001).

Finally, in settings where men are portrayed and perceived as the main breadwinner, women's ability to offer family assets as collateral and their incentives to invest in productive activities are influenced by family dynamics that are likely to prioritize men's investments (Ospina, 1998). According to ILO (2008), women in Kenya make up nearly half of small and medium enterprises owners and 40 percent of small holder farm managers yet they have less than 10 percent of the available credit and less than 1 percent of agricultural credit.

\section{Gender discriminatory factors}

Finally, women's access to financial resources is also limited by biased lending practices that emerge when financial institutions in the area consider them smaller, less experienced and therefore less attractive clients, or when institutions lack the knowledge to offer products tailored to women's preferences and constraints (Fletschner, 2009). The extent to which institutions reach out to women and the conditions under which they do vary noticeably, but women are at a disadvantage when an institution does not fund the type of activities typically run by women, when it does not accept female guarantors, when its requirements are not clear or widely known or when, as it is typically the case, loans to women are smaller than those granted to men for similar activities (Fletschner, 2008a; World Bank, 2008b; Ospina, 1998). This lack of clarity and transparency enables employees responsible for loan approvals to frame them as special favours that women are often unable to repay. The most common forms of repaying such favours-such as inviting loan officials for a 
drink or for dinner or the giving of bribes - are not considered acceptable behaviour for women (Ospina, 1998 and Lycette and White, 1989).Combining these elements and acknowledging that, compared with men, women tend to have more limited control over resources accepted as collateral, less access to information, to be more risk averse and face a different set of activity-regulating social norms and family rights and responsibilities, it is easy to see that the type of financial products they need, the conditions under which they are willing to participate in formal financial markets and their ability to meet their financial needs differs dramatically from those of their male partners. Supporting these arguments, quantitative studies in Paraguay, Malawi and Bangladesh find that women are more likely to be credit constrained than men, and the factors affecting whether or not they are able to meet their needs for capital are different (Fletschner, 2009 and Diagne et al., 2000). Similarly, Floro (2002) finds that women and men differ in their savings patterns, a difference that she attributes to differences in risk attitudes, options and constraints.

\section{Institutional theory}

This theory focuses on the role of social, economic and political systems in which entrepreneurship operates and their choices and behaviour is surrounded (Baughn, Chua Neupert, 2006). Economic environment includes the general wealth of the society, economic stability, as well as capital availability. Political environment includes freedom, Property rights, as well as decentralization of political power. Socio-cultural environment includes social and cultural norms, and beliefs (Shane 2003). Busenitz, Gomez and Spencer (2002) strongly believe that entrepreneurial activities are largely shaped by their institutional environments. Formal institutions mainly influence the extent to which female entrepreneurship is able to develop, and the characteristics of their businesses, as noted by Welter and Smallbone (2003). While formal institutions such as laws and policies can create opportunity fields for entrepreneurship, informal institutions such as values, norms, and the general attitude of a society toward entrepreneurship can strongly influence the collective and individual perception of entrepreneurial opportunities (Welter et al, 2003). Cultural norms and values help to shape the way into entrepreneurship and more specifically influence an individual's tendency towards entrepreneurship. The evolving institutional frameworks might constrain women's formal integration into the emerging market economy due to redefined and changed gender roles, thus restricting their access to the external resources that are needed in order to start, run and realize a successful business enterprise.

\section{Conceptual frameworks}

These are concepts that are put together as a map for the study to show the relationship of research variables (Mugenda \& Mugenda, 2008). It is used to explain how the independent variables affect the dependent variable. In this study, the conceptual framework is based on four crucial variables that are assumed to limit the accessibility of business finance by women entrepreneurs in Kenya. These include: lack of collateral, insufficient of information, cultural norms and gender discrimination factors of the lending institutions.

\section{Research Gaps.}

Over the past decades, women entrepreneurship has been studied and several challenges have been noted to affect the performance of their enterprises negatively. Limited access to finance has been identified as the key constraint globally (Minniti, 2009; Jamali (2009)

Despite the resources available, from private and public development finance institutions, only few women are able to access them. Studies indicate that many women rely largely on support

from husbands, partners and relatives to successfully start and grow business (Jennings and McDougal, 2007). Majority of the scholars have emphasized on common problems affecting SMEs (King and McGrath 2002, Wanjohi and Mugure, 2008) etc.

Very little has been studied on the reasons as to why female entrepreneurs face daunting challenges in accessing business finance in Kenya. The information available was mainly conducted on women living in rural areas where cultural norms are vastly inevitable.

\section{Research Methodology}

Kothari (2004) defines a research design as the conceptual structure within which research is conducted. The research design used ensured collection of relevant information with minimal expenditure of effort, time and money. This study employed a survey method to collect data. A survey is an attempt to collect data from members of a population in order to determine the current status of that population with respect to one or more variables, (Mugenda \& Mugenda, 2003). A mix of element of study is appropriate for representative purpose since the study elements are engaged in a variety of commercial activities. The qualitative data was used particularly to supplement the strength of the quantitative aspect.

\section{Sampling frame}


The sample frame included all women entrepreneurs who were operating registered businesses by end of December 2012. These women were drawn from the six wards which are within Ruiru Municipality.

Table 3.1 Sample frame

\begin{tabular}{|l|c|c|c|}
\hline Category & Population & Percentage & Sample size \\
\hline Wholesale & 37 & $10 \%$ & 4 \\
Beauty shop & 174 & $10 \%$ & 17 \\
Groceries & 345 & $10 \%$ & 34 \\
Clothing and design & 233 & $10 \%$ & 23 \\
Hair styling & 534 & $10 \%$ & 53 \\
Restaurants & 32 & $10 \%$ & 3 \\
Hardware & 55 & $10 \%$ & 5 \\
Service repair/workshop & 19 & $10 \%$ & 2 \\
Health/entertainment & 2 & $10 \%$ & 1 \\
Education & 3 & $10 \%$ & 1 \\
ICT & 39 & $10 \%$ & 4 \\
\hline Total & $\mathbf{1 4 7 3}$ & $\mathbf{1 0 \%}$ & $\mathbf{1 4 7}$ \\
\hline
\end{tabular}

Source; Ruiru Municipal council (2012)

\section{Research instruments}

Data collection instrument is a device used to collect data in an objective and a systematic manner for the purpose of the research, data collection instruments can be questionnaires, interviews, schedules and available records (Orodho, 2009). According to Kothari (2006) the information obtained from questionnaires is free from bias and researchers influence and thus accurate and valid data was gathered.

Each item on the questionnaire was developed to address specific objective of the study. The questionnaire employed both open-ended and closed-ended structured questions. The questionnaire employed a Likert scale giving options that the respondent was to choose from, and a few responses that were open-ended which obtained rich data concerning the subjective thoughts and viewpoints evoked by the different responses related to the variables of the study. The questionnaires were self administered to all the respondents in the sample size.

\section{- Data analysis and presentation}

Once data was collected, the first task was to check for the instrument's completeness, accuracy and uniformity.

The study generated both qualitative and quantitative data. Descriptive statistics data analysis method was applied to analyze both quantitative data. Data obtained from the questionnaires was processed through editing and coding and then entering the data into a computer for analysis using descriptive statistics with the help of Statistical Package for Social Sciences (SPSS) version 17, which offers extensive data handling capabilities and numerous statistical analysis procedures that analyses small to very large data statistics (Bell,2007). Descriptive statistics was used to compute measures of central tendencies and measures of variability (Bell, 2007). The analyzed findings were then presented in form of frequency tables, percentages and bar charts since they are user friendly and gives a graphical representation of the different responses given by the respondents.

\begin{tabular}{l} 
Data analysis methods \\
\begin{tabular}{|l|l|}
\hline research objective & method of analysis \\
\hline $\begin{array}{l}\text { 1. To find out the extent to which lack of collateral limits accessibility of finance by } \\
\text { women entrepreneurs. }\end{array}$ & Frequencies and percentages, Chi-square \\
$\begin{array}{l}\text { 2. To determine the influence of cultural norms on the accessibility of business } \\
\text { finance by women entrepreneurs. }\end{array}$ & Frequencies and percentages, Chi-square \\
3. To find out the extent to which insufficient information limits accessibility of \\
business finance by women entrepreneurs. \\
$\begin{array}{l}\text { 4. To determine the gender issues that limits the accessibility of finance by women } \\
\text { entrepreneurs. }\end{array}$
\end{tabular} \\
\hline
\end{tabular}

\section{Lack of Collateral}

\section{Data Analysis And Discussions}

Most women entrepreneurs (60\%) receive their finance from informal sectors such merry-go-rounds; this is because these informal sectors do not require any collateral as security for loans. MFIs are the second also preferred institution (22\%) followed by SACCOs (10\%) then commercial banks (8\%). On the other hand, NGOs rarely fund business entrepreneurs in their own business 
Table 4.1 Lack of collateral

\begin{tabular}{|c|c|c|c|c|}
\hline & & & $\mathrm{X}^{2}$ value & P-Value \\
\hline - & Startup capital was not enough & & 48.133 & 0.000 \\
\hline$\bullet$ & Difficult financing for my startup capital & 76.800 & 0.000 & \\
\hline • & Required to produce tangible assets to access credit & 76.200 & 0.000 & \\
\hline • & Most women do not own assets required to secure credit financing & 147.330 & 0.000 & \\
\hline • & $\begin{array}{l}\text { Lack of collaterals is the single greatest obstacle to women } \\
\text { neurs aspiring to seek credit financing }\end{array}$ & 83.333 & 0.000 & \\
\hline • & $\begin{array}{l}\text { Credit finance available for women who do not require collateral } \\
\text { very limited }\end{array}$ & 56.033 & 0.000 & \\
\hline
\end{tabular}

From table 4.1, the following observations are evident;

At $95 \%$ confidence level lack of collateral has significance effect to access of finance by women entrepreneurs since the computed P-Values are less than the significance level of 0 . 05. This designates the importance of collateral in acquiring credit facilities from formal financial institutions. Therefore since most women do not own the tangible assets which acts as collateral, they become disadvantaged. They are forced to look for other alternatives available sources of finance like borrowing from friends and family members.

Table: 4.2 lack of collateral is the single greatest obstacle to women entrepreneurs seeking credit financing

The findings shows that $62.5 \%$ of women respondents agreed unanimously lack of collateral limits credit accessibility of women entrepreneurs at a very great extent. Their businesses are therefore seen as more risky and the type of credit they get has high interest rates and payable within a shorter period .This could be due to the fact that collateral acts as security for loan and is used by most money lending institutions to avoid bad debts.

\section{4: Information on Finance}

\section{Table: 4.3 level of education of the respondents}

The result of the research clearly shows that very few women entrepreneurs have high qualification in education. This is illustrated by a very small percent of women have attained the degree level (11.7\%). Those who have attained diploma level accounted for $21.7 \%$ and certificate level $45.8 \%$. This could further explain why most women involve in small scale businesses instead of large scale. It could be the fact that they do not have enough entrepreneurial skills to manage large scale businesses. On the other hand, many women who gets an opportunity to advance in education go ahead to seek formal employment. A few of those who are not lucky to secure a formal position are the ones who turn into entrepreneurship as their last resort.

The study also revealed that many of the women who have attained the formal training did not have any exposure to entrepreneurial training. This shows that many courses that are being offered do not equip the learners with proper skills to operate businesses.

\section{Table 4.4 Insufficient Information on finance}

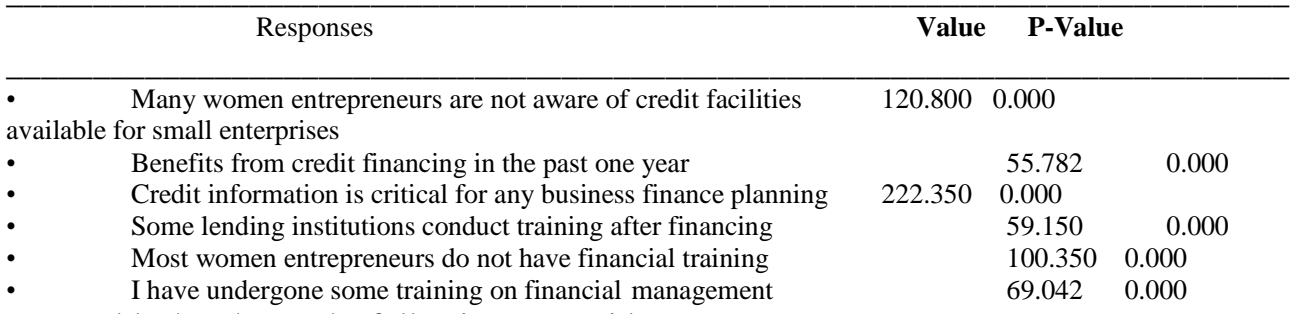

From table 4.6 above, the following was evident;

At $95 \%$ confidence level, insufficient information on finance has significance effect to access of business of business finance since the computed P- Values are less than the significance level of 0.05.The result clearly indicates that very few institutions conduct basic finance training and there are very few women entrepreneurs 
who have undergone basic financial management training. Due to this reason, it becomes difficult for them to be able to maintain books of accounts that could help them to monitor the financial performance of the business. At the end their businesses are faced with a problem of working capital and they therefore cannot be able to meet their financial obligations.

\section{Cultural Norms}

Table 4.5 Effect of cultural norms on finance accessibility

\begin{tabular}{llrr}
\hline & \multicolumn{1}{c}{ Responses } & \multicolumn{2}{c}{ Value P-Value } \\
\hline - & Some family roles do not support participation of women in business & 135.200 & 0.000 \\
- & Some business activities are seen as exclusive male & 79.850 & 0.000 \\
& Few women own a business account & 40.833 & 0.000
\end{tabular}

From table 4.3 above, the following was observed;

At 95\% confidence level, cultural norms have a significance effect to access of business finance by women entrepreneurs since the computed P-Values are less than the significance level of 0.05. Our African culture has been a bit rigid where the place of a woman has been viewed to be in the kitchen apart from taking care of the children. This has denied some of them to acquire formal education to a higher level. Those who are lucky to join formal education majority of them end up in courses that are traditional-role based like hairstyling, retail and tailoring which they can operate as they take care of the family chores. Those who are greatly affected are those who have young families (as revealed by the study, aging between 21-35 years) and cannot afford to pay for extra services taking their young children to day care. Therefore they are denied a chance to venture in maledominated chores such as carpentry and also their chances of meeting lending agents are reduced because many of their businesses are located near their homes where few of these agents reach.

Gender Discrimination Factors

Table 4.7 Effect of gender bias

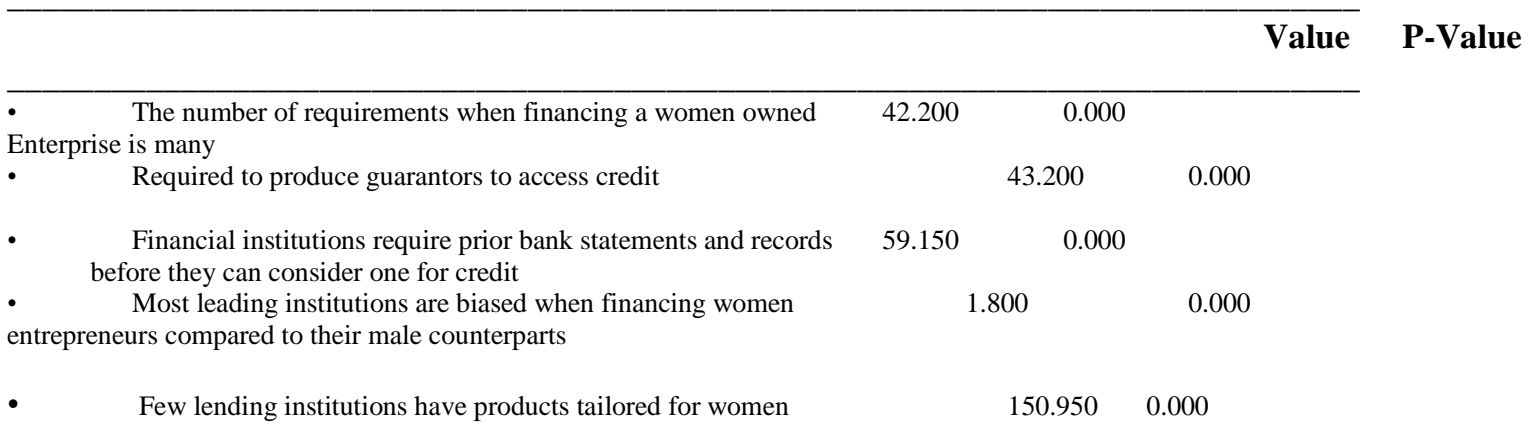

From table 4.7 above, it was evident that at $95 \%$ confidence level, gender bias has a significance effect to access of business finance by women entrepreneurs since the computed P-Values are less than the significance level of 0.05 when lending to female entrepreneurs. The expectation is that with the campaign on Gender Equality, more women should be enjoying equal treatment as their male counterparts by the financial institutions. This is not the case on the ground because even after introduction of Youth Enterprise Fund and Women Enterprise Fund programs by the government, it has failed to establish independent systems of administering the same. This therefore leaves room for the financial intermediaries to take advantage of these weaker government systems.

\subsection{Conclusion}

\section{Conclusions And Recommendations}

Based on the study, the research seems to reveal similar findings by the preceding studies although additional observations have been made by the researcher.

To begin with, the research has revealed there is no doubt that women entrepreneurs face a lot of challenges while accessing credit. This is similar to report by GoK (2005) in the sessional paper no. 2. This limits their potential from graduating from small scale to large scale business Siwadi et al (2011). The study also indicates that the average monthly income of these businesses is below Ksh. 50,000. This low income can be attributed to the gender role that a woman is given in the society. For example the African culture has always seen a woman as a housewife. Her major responsibility is to provide for domestic necessities besides taking care of the children hence the kind of business one can afford to run is as mall one to feed the family. With this mentality, majority enter into business for survival- motive rather than profit-motive. These businesses therefore end up 
producing very little income. Due to this low income, small enterprises find it harder to get financing from formal lending institutions (OECD, 2006). This is because they are perceived more risky and non-profitable in terms of profits contribution to the financier since the kind of credit they receive is usually of smaller amounts payable within a shorter period. The financier therefore feels that the transactional costs are higher yielding little or no profits.

Further the research reveals that the number of women who have graduated with a degree or a diploma and are in business is very low. This could be interpreted in two ways. One, majority of educated women are absolved in formal careers and only the few unlucky who do not get an opportunity immediately decides to start a business as they wait for the opportunity to come. The second assumption is that most women especially those from disadvantaged backgrounds find it difficult to acquire formal education and even those do, the highest level they manage is either a certificate besides O-level. The other observation is that even those who succeed to receive the formal education at any level, the training they undergo is not entrepreneurial in nature. This is in agreement with the sessional paper no.2 (GoK 20o5) which indicated that the capacity of resources in most institutions is limited compared to demand. Therefore the graduates who leave the institutions are inadequately and inappropriately prepared.

Lastly, the study confirmed that lack of collateral especially from formal banks is a greater hindrance to credit accessibility by women entrepreneurs. This is also noted in the World Bank report (2012) on Women and Law. This is due to lack of ownership of tangible assets like land, which are used as assets to secure credit. However, this problem is being solved slowly by some financiers especially the microfinances and Sacco's which consider other assets like domestic furnitures end animals to act as security for smaller loans. On the other hand, however small the businesses operated by women seem to be small, they have been noted to greatly contribute to the economic welfare of the country. All is not lost as there seems to be a light at the end of the tunnel especially with the new constitution which gives women equal rights, socially, politically and economically.

\subsection{Recommendations}

The contribution of women entrepreneurship to the economy has been globally accepted in the previous research. Therefore based on the findings of the study, the researcher came up with the following recommendations;

First, financial institutions should come up with a special package of products which are not mainly pegged on collateral as the major requirement of securing finance by women entrepreneurs. This will boost confidence in women entrepreneurs who may require to expand their business enterprises but shy aware due to stringent rules.

Secondly civic education and publicity should be conducted by the potential financiers and government line ministry on the need of women empowerment to do away with negative mentality that hinder women entrepreneurs from myth that a small business cannot access substantial credit just like an established firms.

Thirdly, the policy makers should emphasize on entrepreneurship education in institutions of learning. This can be made more practical by introduction of business incubation centers in the institutions, where students can practice and sharpen their entrepreneurial skills before they leave school. This will make entrepreneurship look more practical to the learner.

Lastly, the research has revealed that although women entrepreneurs face similar challenges in accessing business finance there are substantial variations of need by different cadres of marital status. Married women seem to enjoy unrivalled advantage compared to other levels of status (single, divorced and widowed). Therefore the researcher recommends further studies to be done to establish these variations of need among women entrepreneurs with a view to determine whether they affect their performance in running their businesses.

\section{Reference}

[1]. Agarwal, B. 2003. Gender and land rights revisited: Exploring new prospects via the state, family, and market. Journal of Agrarian Change, Vol. 3

[2]. Aina, L. 2006. Information provision to farmers in Africa: The library-extension service linkage. Paper presented at the World Library and Information Congress: 72nd IFLA General Conference and Council, Seoul, Korea.

[3]. Baughn, C.; Chua, B.; Neupert, K. (2006) The Normative Context for Women's Participation in Entrepreneurship:

[4]. Bell, C. (2007). Using SPSS, Journal of Statistics, 22(1)

[5]. Bezner Kerr, R. 2008. Gender and agrarian inequality at the local scale in S.S. Snapp and B. Pound. Eds. Agricultural systems: Agroecology and rural innovation for development, London, Academic Press.

[6]. Brown, W. (2001).Micro insurance -The risks, perils and opportunities. Small Enterprise Development, Vol. 12(1):

[7]. Cole, S. T. Sampson and B. Zia. 2009. Financial literacy, financial decisions, and the demand for financial services: evidence from India and Indonesia. Working Paper 09-117. Cambridge, MA, Harvard Business School.

[8]. Deere, C. and M. Leon. 1997. Women and land right

[9]. s in the Latin American neo-liberal counter- reforms, Working Paper No. 264. Women in International Development, East Lansing, MI., Michigan State University. 
[10]. Eckhardt, J. and Shane, S. (2003) Opportunities and entrepreneurship. Journal of Management, Vol. 29 No. 3,

[11]. Entrepreneurship Research and Practice. Academy of Management Review, Ju12007, Vol. 32 Issue 3,

[12]. Esenu, B., S. Ossiya, D. Serunkuma, J. Oluka, D. Alin, B. Owesigire, G. Ebiyau and B. Olokojo. 2005. Positioning agro-pastoral women in livestock production:

[13]. Fletschner, D. 2008a. Rural women's access to capital: Intra-household bargaining and social effects., Saarbrucken, Germany, VDM Publishing House.

[14]. Fletschner, D. 2008b. Women's access to credit: American Journal of Agricultural Economics, Vol. 90(3

[15]. Fletschner, D. 2009. Rural women's access to credit: Market imperfections and intra-household dynamics. World Development, Vol.

[16]. Fletschner, D. and D. Mesbah. 2010. Rural women's access to information: Do spouses share what they know? (Manuscript

[17]. Government of Kenya (GoK), (1999). National Baseline Survey. Ministry of Planning and National Development, Government Printers: Republic of Kenya.

[18]. Government of Kenya (GoK), (2005). Sessional Paper No. 2 of 2005 on Development of Micro and Small Enterprises for Wealth and Employment Creation for Poverty Reduction.

[19]. Government of Kenya (GoK). (1992). Sessional paper No. 2 of 1992 on Small Enterprise and Kenya. Government Printers.

[20]. http://www.gemconsortium.org accessed on May $24^{\text {th }}, 2013$

[21]. http://wbl.worldbank.org accessed on $25^{\text {th }}$ may 2013

[22]. Innovation,International Finance Corporation (IFC), (1999). Gender and Economic Growth Assessment in Kenya. Washington D.C. Draft.

[23]. International Finance Corporation (IFC), (2006). Gender and Economic growth Assessment of Women Etrepreneurs in Kenya. Washington D.C draft.

[24]. International Labour Organizations (ILO), (2008). Women Entrepreneurs in Kenya: FactorsAffecting Women Entrepreneurs in Micro and Small Enterprises in Kenya. ILO, Regional Office for Africa, Geneva.

[25]. Jamali, Dima (2009) Constraints and opportunities facing women entrepreneurs in developing countries: A relational

[26]. Jennings, J, McDougald, E (2007) Work-Family Interface Experiences and Coping Strategies: Implications for Joppe, P. (2000). Research Methodology. Third Edition. Pearson Publishers.London.UK.

[27]. Kothari, C.R.(2004). Research methodology. Chennai, Age International Publishers Limited.

[28]. Marlow, S. (2002) Women and self-employment: A part of or apart from theoretical construct?

[29]. Miller, B.A. 2001. Empowering women to achieve food security: Rights to livestock. Washington. DC, International Food Policy Research InstituteWorld Bank.

[30]. Minniti, M. \& Bygrave, W. (2001). A Dynamic Model of Entrepreneurial Learning. Entrepreneurship, Theory and Practice, Spring

[31]. Mugenda, O.M. and Mugenda, A.G. (19990. Research methodology: Qualitative and quantitative approaches. Nairobi: Acts Press

[32]. National Baseline Survey. (1999). National micro and small enterprise baseline survey. Nairobi: ICEG and K-REP.

[33]. Ngimwa, P., D.N. Ocholla, and J.B. Ojiambo. 1997. Media accessibility and utilization by Kenyan rural women. International Information and Library Review, Vol. 9:

[34]. Orodho, (2003). Essentials of educational and social sciences research methods:Qualitative and Quantitative Approaches. Nairobi Acts press.

[35]. Ospina, R. 1998. Perspectiva de género en la misión rural: Para dotar de poder a las mujeres. Misión Rural Proyecto Proequidad GTZ/CNP, Santa Fé de Bogotá, Colombia. perspective. Gender in Management: An International Journal, 2009, Vol. 24 Iss: 4

[36]. Primo, N. 2003. Gender issues in the information society. Paper prepared for the World Summit on the Information Society, Paris, France, UNESCO. Sesan L. \& St-onge A. (2001). Support for Growth-Oriented Women Entrepreneurs in Ethiopia, Kenya and Tanzania, an Overview report, International Labour office, Geneva

[37]. Stevenson, L. and St-Onge, A. (2005). Support for Growth-Oriented Women Entrepreneurs in Kenya. International Labour Organization, Geneva.

[38]. Stone, J. R. (2008). Youth Run Enterprises: Successes, Barriers and Policy Implications,Minessota, USA.

[39]. Storey, D. J. (2003). Entrepreneurship, Small and Medium Sized Enterprises and Public Policies. The Handbook of Entrepreneurship, Kluwer: London

[40]. Tipilda, A. and P. Kristjanson. 2008. Women and livestock development: A review of the literature. ILRI Innovation Works Discussion Paper 01-08. Nairobi, International Livestock Research Institute

[41]. UNDP.2007. Human Development Report 2007. New York, NY.

[42]. USAID. 2003. Women's property and inheritance rights: Improving lives in changing times. Office of Women in Development, Bureau for Global Programs. Washington, DC.

[43]. Wanjohi, A.M., \& Mugure, A. (2008). Factors affecting the growth of MSEs in rural areas of Kenya: A case of ICT firms in Kiserian Township, Kajiado District of Kenya World Bank. 2008b. Gender in Agriculture Sourcebook. Washington DC

[44]. Zinbarg, M. (2005). Research Methods, Second edition. New Jersey. USA Pearson Publishers 